\title{
Learning from the Iraq Museum
}

\author{
Donny George Youkhanna*
}

INTRODUCTION

The Iraq Museum was founded in 1923 when Gertrude Bell, the British woman who helped establish the nation of Iraq, stopped the archaeologist Leonard Woolley from taking out of the country all of his extraordinary third-millennium B.C.E. finds from the ancient Sumerian city of Ur (esp. the jewelry of the royal cemetery) ${ }^{1}$ for division between the British Museum in London and the University of Pennsylvania's Museum in Philadelphia. She believed that the Iraqi people should have a share of this archaeological discovery made in their homeland and, thereby, started a museum in central Baghdad, pressing into service two rooms in an Ottoman barracks as its very first galleries. Material from ongoing excavations continued coming into this young museum, and in 1936, it moved to another building likewise on the eastern side of the Tigris River. The museum continued enlarging its collection. Finally, the Iraqi government decided to construct a modern building for this national museum. Completed in 1960, the new museum was built on the Tigris River's west bank. Moving the collection from the old building and installing it in the new museum's galleries took four years. The present Iraq Museum opened in 1964, and in 1982, six large galleries were added to the building, for a total of 22 galleries, plus an ample lobby and reception area at the main entrance.

The Iraq National Museum is one of the best archaeological museums in the world, containing the material evidence for the development of civilized human society from the very begin-

\footnotetext{
* I would like to thank McGuire Gibson, from the Oriental Institute of the University of Chicago, and Museum Review Editor Beth Cohen for their help in the preparation of this review.
}

ning of its history. This entirely documented collection of finds from the cradle of civilization encapsulates the most essential cornerstones of our modern life, including agriculture, writing, laws, mathematics, astronomy, the arts, and warfare.

\section{THE MUSEUM UNDER ATTACK}

The protection of a museum's holdings in times of warfare or civil unrest is a multifaceted and complicated issue. Because museums present themselves as - and are routinely portrayed by the media as-storehouses and display venues of treasure, they become targets of looting by organized gangs and by people from the street. Because invading armies see all armed personnel as potential enemies, guards at museums and other cultural institutions tend to be attacked or to slip away as fighting nears. If the invading army does not take responsibility for securing cultural institutions that have lost their guards, looters quickly take advantage of the vacuum in civil order. This scenario resulted in the looting at the Iraq National Museum on 10-12 April 2003 and also at dozens of other Iraqi cultural institutions, including the National Library, the National Academy of Arts, institutes of music, dance, and art, and universities in Baghdad and elsewhere. Likewise, organized looting of archaeological sites, which had begun during the mid 1990s in the south of Iraq, resumed at a greatly increased rate while the invasion was taking place, and it continues unabated. ${ }^{2}$

Since the Iraq National Museum was a prominent potential target of looting, before

\footnotetext{
${ }^{1}$ Woolley and Moorey 1982.

${ }^{2}$ Emberling and Hanson 2008; Myers 2010, 25 June.
} 
the start of the operation in March 2003, several attempts were made in meetings with U.S. Pentagon and State Department officials to call attention to its importance and the threat to its holdings. In particular, it was pointed out that in the uprisings that occurred in the aftermath of the 1991 war, nine of the 13 regional museums in the south and north of the country had been damaged and looted, resulting in the loss of about 5,000 artifacts, fewer than 10\% of which have been recovered. As a result of those losses, the Antiquities Service no longer put any genuine objects on display in regional museums (except for the Mosul Museum), but instead installed casts and photographs. Some museums at prominent archaeological sites, such as Babylon and Hatra, did still display some real objects, but these sites were well guarded and were thought not to be as vulnerable as small museums in the centers of provincial towns.

In the months leading to the 2003 war, media attention was drawn to the Iraq Museum in interviews with American and European academics and with Iraqi officials. The author of this review, then Iraqi director general for research but not yet responsible for the museum, was quoted in one news report as saying that the objects from Hatra and the Mosul Museum were being transferred to the Iraq National Museum, where it was thought that they would be safer. He was aware that, as in the first Gulf War, the museum itself would be put on a no-target list. William K. Polk, a Middle East expert, visited Baghdad before the invasion and tried to convince the Iraqi authorities to send the museum's collections out of the country for safekeeping. Given that dismantling the museum's public galleries and depositing most of the displayed items in a secret storeroom alone required more than two weeks of work, it is highly unlikely that the museum's staff could have emptied the galleries and the storerooms in time to send the collections abroad. How anyone could have kept these hundreds of thousands of items intact and accounted for during such a move was not addressed. It is unlikely that any museum anywhere is capable of dismantling its collections and shipping them off with any hope of maintaining the integrity of the artifacts and their corresponding identifications. Given the reduced staff size and the loss of trained museum professionals as a result of 13 years of sanctions on Iraq because of the Iraqi invasion of Kuwait in 1990, it would have been impossible to undertake such a course of action in Baghdad.

\section{THE MUSEUM'S DOCUMENTATION}

One of the major problems with the Iraq National Museum, as with many museums, was the lack of a complete inventory, including photographs of each item. Yet a very fine master catalogue in large ledgers, recorded in English and Arabic, has existed since the museum was founded in the early 1920s; this master could be correlated with excavation find catalogues, and thus the present location of an item could be discovered from notations on the ledgers and also in museum display case and shelf logs. However, the maintenance of such records was seriously compromised because of the abovementioned layoffs of personnel during the sanctions regime in the 1990s. A massive influx of newly excavated objects derived from salvage digs carried out from the late 1990s until 2003 by the State Board of Antiquities and Heritage (SBAH), the parent body of the museum, only added to the difficulty. These salvage operations had themselves been mounted to stop the looting of major sites in the south. Prior to 1991, for more than 40 years, antiquities looting had been almost nonexistent in Iraq, but the lack of government control of the southern countryside under the sanctions allowed industrial-scale pillaging of many sites. The salvage operations, carried out by the already overworked personnel of the SBAH and the Iraq Museum, including the director general of museums, did impede the looting somewhat. They also resulted in the exposure of important buildings and the recovery of thousands of artifacts, but these finds presented a major problem to the museum's staff, which had to try to process them. Some of the more significant objects were recorded fully, but others were set aside to be dealt with later. Steel trunks holding these salvaged finds were pilfered during the looting of the aboveground storerooms in April 2003.

The necessity of dismantling the public galleries several times since 1980 exacerbated the problems. At the beginning of the IranIraq War, when rockets often came down on Baghdad (including a particularly deadly one that fell within $200 \mathrm{~m}$ of the museum in 1984), the public galleries were dismantled, except for very large, permanently fixed objects, such as Assyrian reliefs, Islamic building facades, and massive wooden doors. The movable objects were put into storage, both above- and below- 
ground, resulting in some subsequent damage from humidity. At the end of the Iran-Iraq War in 1988, the galleries were reinstalled; but now three of them were devoted to the astonishing finds from the Neo-Assyrian Queens' Tombs of the eighth century B.C.E., which the Iraqis had found at Nimrud during 1988-1989. ${ }^{3}$ In late 1990, with the Gulf War about to begin, the displays were once again dismantled and put into storage, with many of the iconic and valuable objects, such as the Ur Cemetery gold and most of the finds from the Neo-Assyrian Queens' Tombs, transferred to a deep vault of the Central Bank. During the 1990s, because of the sanctions and the possible renewal of warfare, the museum remained closed except for some small, short-lived exhibitions. The objects stayed in the Central Bank, and even when the museum was reopened in 2000 , and most of the exhibits were arranged as they had been, the finds from the Queens' Tombs were no longer on display, except for photographs of some objects. Some of the most famous items from the Ur tombs were likewise shown by means of photographs in the cases that used to hold the objects.

In anticipation of the 2003 war, the SBAH made several decisions intended to safeguard objects. First, all portable objects from Mosul, Babylon, and Hatra, including some life-sized statues from Hatra, and some objects from the other provincial museums, were transferred to the Iraq National Museum. Second, a group of five persons was given the responsibility of dismantling and hiding the portable objects from the museum's public galleries in a secret storage location known only to the five; they swore on the Qur'an not to reveal the secret. Third, sandbags and foam were placed in front of or upon some of the large, immovable objects, such as the Assyrian reliefs. Fourth, the basic object records and many of the most important reference books from the Antiquities Library were hidden off-site in a bomb shelter, along with almost 40,000 manuscripts from the Manuscript House (most of them dating to the Islamic period, some more than 1,000 years old). Fifth, the movable shelving of the Antiquities Library was put in the closed position and welded in order to make the remaining books and journals less accessible to looters. Sixth, windows and doors were barricaded with con- crete blocks, and the steel doors of storerooms and doors meant to segregate specific areas were closed and locked. This reviewer wanted to seal all the outer doors to the museum and the administrative offices of the SBAH but was not allowed to do so, except for a partial barrier placed behind the museum's front entrance.

\section{THE MUSEUM'S GUARDS}

The ultimate protection for any museum is its guards; therefore, a special police unit was placed in a small building in the back of the museum complex, but as the war came close to the museum, its more than 40 guards disappeared. Had they stayed in position, especially in their uniforms, they would most probably have been fired upon. Wisely, as they left, they discarded their uniforms and weapons; this allowed some observers to claim that Republican Guard troops had been on the museum's grounds but had fled. On 8 April, the day the U.S. military arrived at the museum, there were only five persons left. The president of SBAH, Jabbar Khalil, decided that they should leave when he saw a few fedayeen fighters leap over the museum's fence into the front garden. The group left by the back gate, except for a man and his son, who lived at the rear of the museum's grounds. There was no one of authority and no one with fluent English left to surrender the Iraq Museum and SBAH complex, even if the American troops had been willing to take responsibility for it. After a brief fight between the fedayeen and the U.S. troops, which left one shell hole in the symbolic gateway (fig. 1)-a replica of an Assyrian city gate from ancient Khorsabad, of the late eighth century B.C.E., that was converted into the Children's Museum in 1982-and one or two small-caliber bullet holes in the facade of the museum, nothing happened to the complex for more than 24 hours. When the looting began on 10 April (fig. $2)$, the man who had stayed in his house on the museum's grounds went out to the nearby intersection and asked U.S. troops in a tank to drive off the looters. The tank crew, after conferring with commanders, said they could not do so. Late on 12 April, as the press finally arrived at the museum, staff members who lived in the neighborhood came in and began to secure the building, mainly by patching the broken doors (fig. 3).

${ }^{3}$ Damerji [1999]. 


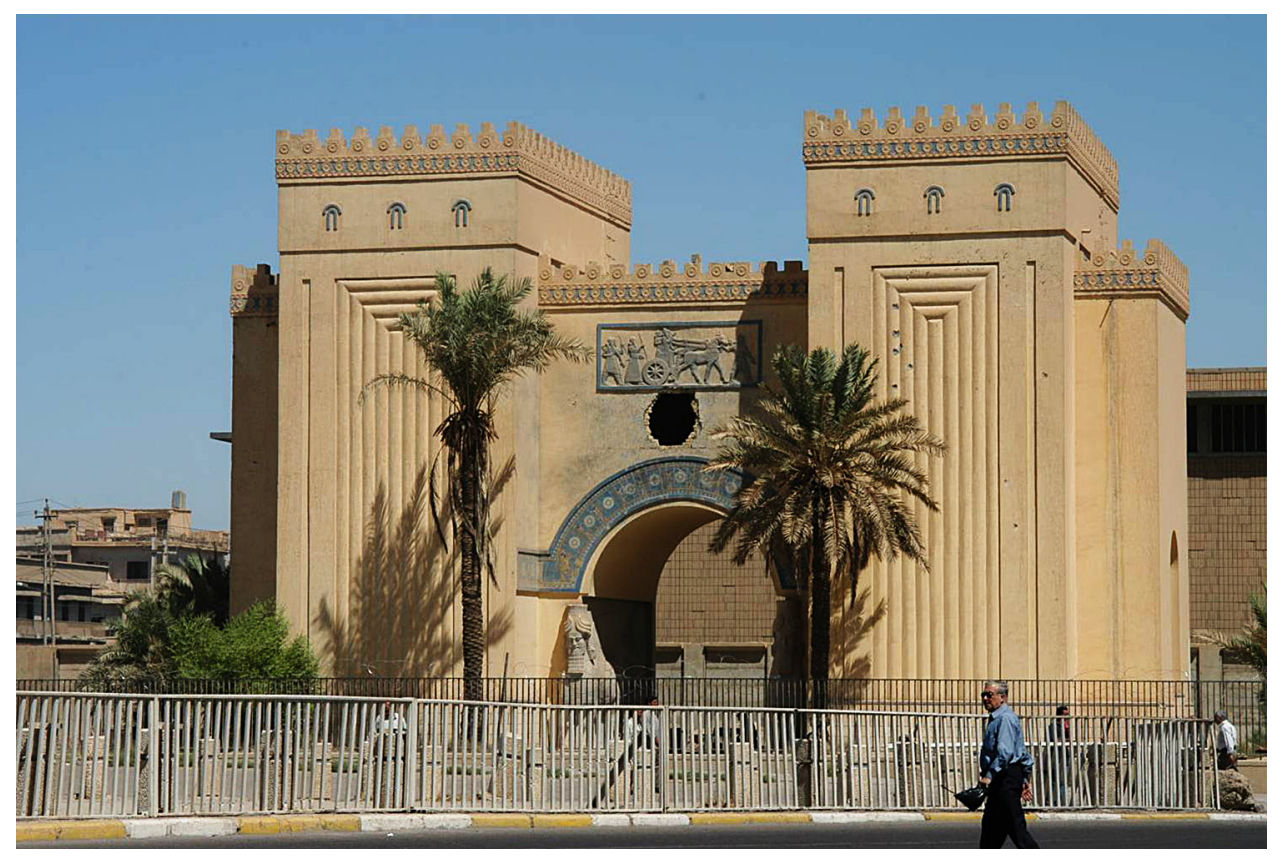

Fig. 1. The Iraq Museum's Children's Museum (replica of an Assyrian city gate from Khorsabad, late eighth century B.C.E.), with a shell hole from fighting in 2003.

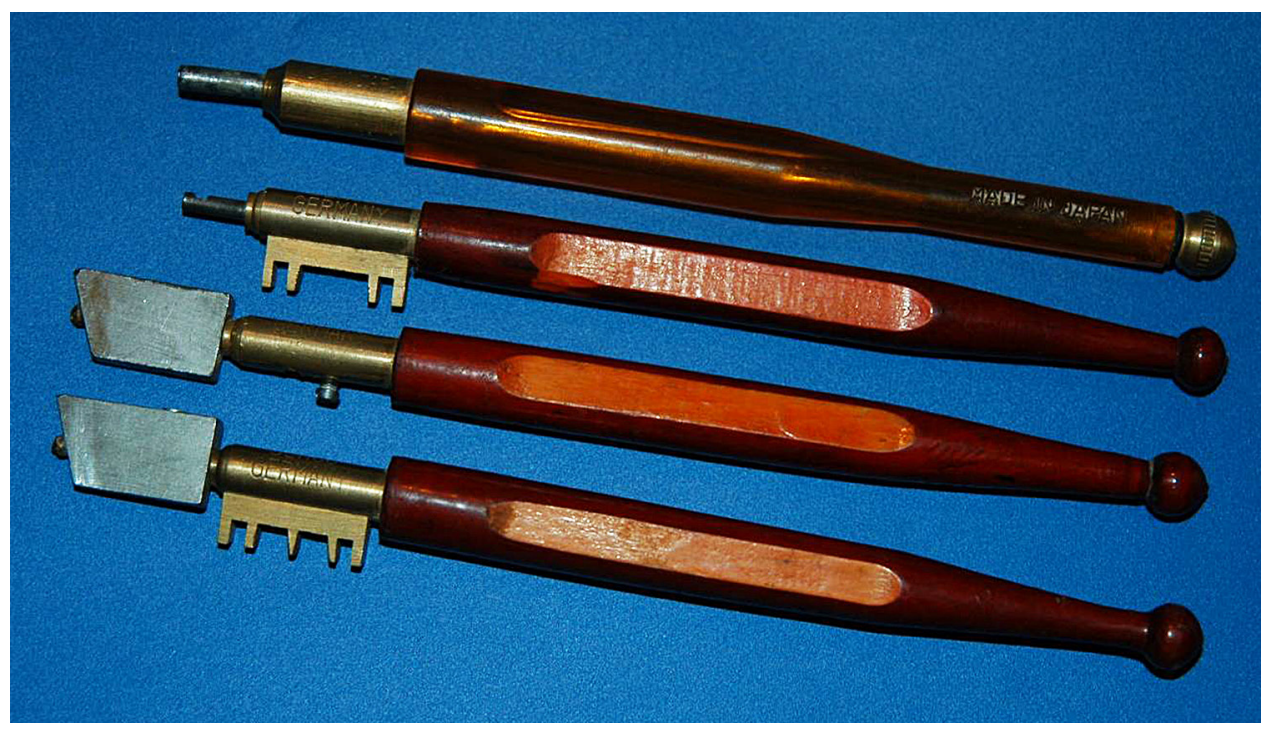

Fig. 2. Glass cutters brought by looters found in the galleries of the Iraq Museum in 2003. 


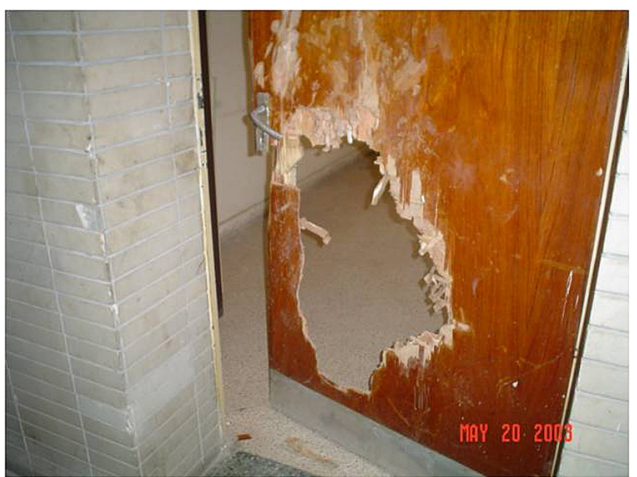

Fig. 3. More than 120 doors in the Iraq Museum and SBAH complex were destroyed in 2003.

\section{PLANS FOR THE MUSEUM'S DEFENSE}

The events leading to the looting of the Iraq Museum and SBAH complex clearly revealed the necessity of having more comprehensive plans for attempting to secure museums and sites. After being named director general of the Iraq Museum, and later as president of SBAH, the author of this review began to develop a schema in which the museum would defend itself.

Actions taken before the war had preserved almost all the items on public display, and those artifacts in the vault of the Central Bank survived, although some were damaged by water. Some important items that had been left, in the display areas or in workrooms, were stolen or damaged (fig. 4). Major losses occurred on account of inside knowledge of the location and contents of underground storerooms (fig. 5). But the use of a secret storage area and the transfer of records and manuscripts to a nuclear shelter away from the museum had preserved thousands of other artifacts.

The schema of the museum's defending itself arose, however, not simply because of what had already happened to the Iraq $\mathrm{Mu}-$ seum and the administrative offices of SBAH but also because the situation has remained insecure. The museum is located in one of the most unstable areas of Baghdad, only two blocks west of Haifa Street, a major street on the west bank of the Tigris River. Even when not subjected to direct attack, the museum's collections are still vulnerable to the vibrations from exchanges of fire and the rumbling of tanks. A major bus terminal-less than $200 \mathrm{~m}$ from the museum-has been subjected to a number of car bombs. Guards, hired since May 2003, have been attacked several times by men firing bursts from automatic weapons while riding in cars passing at high speed through the street in front of the museum. Several guards have been wounded. On one occasion, a Katyusha rocket struck the museum's garden.

Under these conditions, special steps have been taken to protect the museum at times when there may be no guards and the newly installed electronic devices that control the entrances to the museum may not function. Although the Iraq Museum and SBAH complex has been furnished with emergency generators, under certain circumstances it is likely there will still be no electricity and no fuel for the generators. To guard against further losses in periods of chaos, the museum has constructed additional secure storage. It has sealed all metal doors by welding and has built more walls across doorways leading to its collections. Even the administrative areas of the museum that are attached to exhibition galleries have been emptied, and all staff members have been distributed to other departments of the SBAH. This makes it difficult for the museum's staff to carry out routine tasks, much less to continue the inventory of the storerooms in order to gain a more definitive count of the looted objects; but, for now, security takes precedence over all other matters.

Since the basic records of the Iraq Museum had been put in an off-site shelter before the war, it was possible for the museum's staff to retrieve them and begin making an inventory of the storerooms soon after the U.S. troops arrived on 17 April 2003. Had there been a sizable computerized database, the inventory could have been much more efficiently carried out, but the museum had just begun creating a database in the year before the war. Already in the 1980s, the museum had begun using computers for its work, and when 5,000 objects were looted from the regional museums, it was prepared to assemble a database to send to Interpol and other agencies. But the museum had difficulties keeping the computers from crashing because of multiple viruses. And during that earlier effort, it became obvious that photographs or detailed drawings of objects were essential in trying to track down stolen items and secure their return. Without a photograph, it is almost impossible to identify an object. But even when the museum had negatives of objects on file, under the sanctions regime, it could not obtain photographic supplies to make prints. In a few cases, the records kept by foreign excavators could be used to supply 


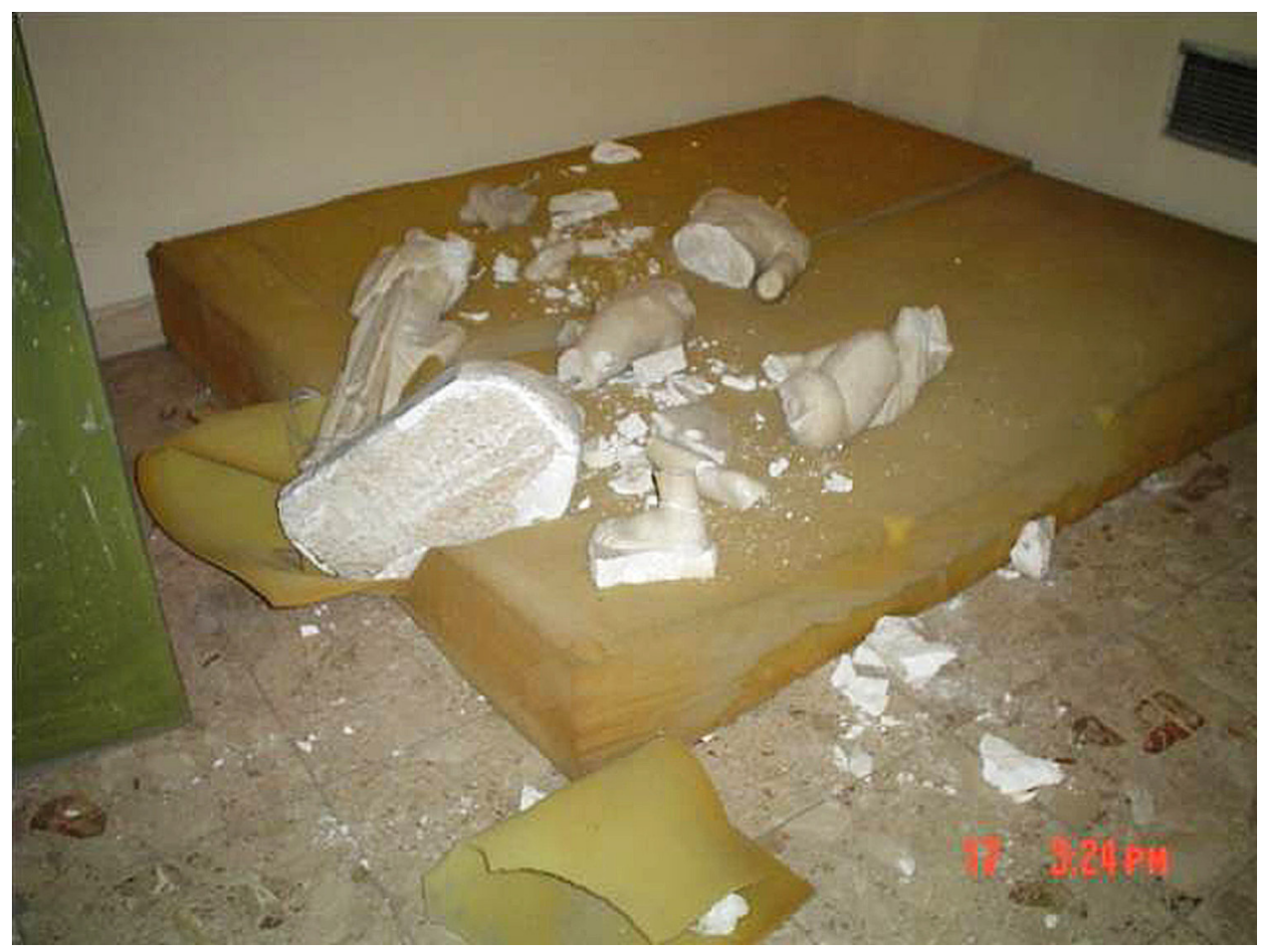

Fig. 4. Roman marble statue of Poseidon from Hatra, ca. 160 C.E., destroyed in the Hatra Hall of the Iraq Museum in 2003 (the head was stolen).

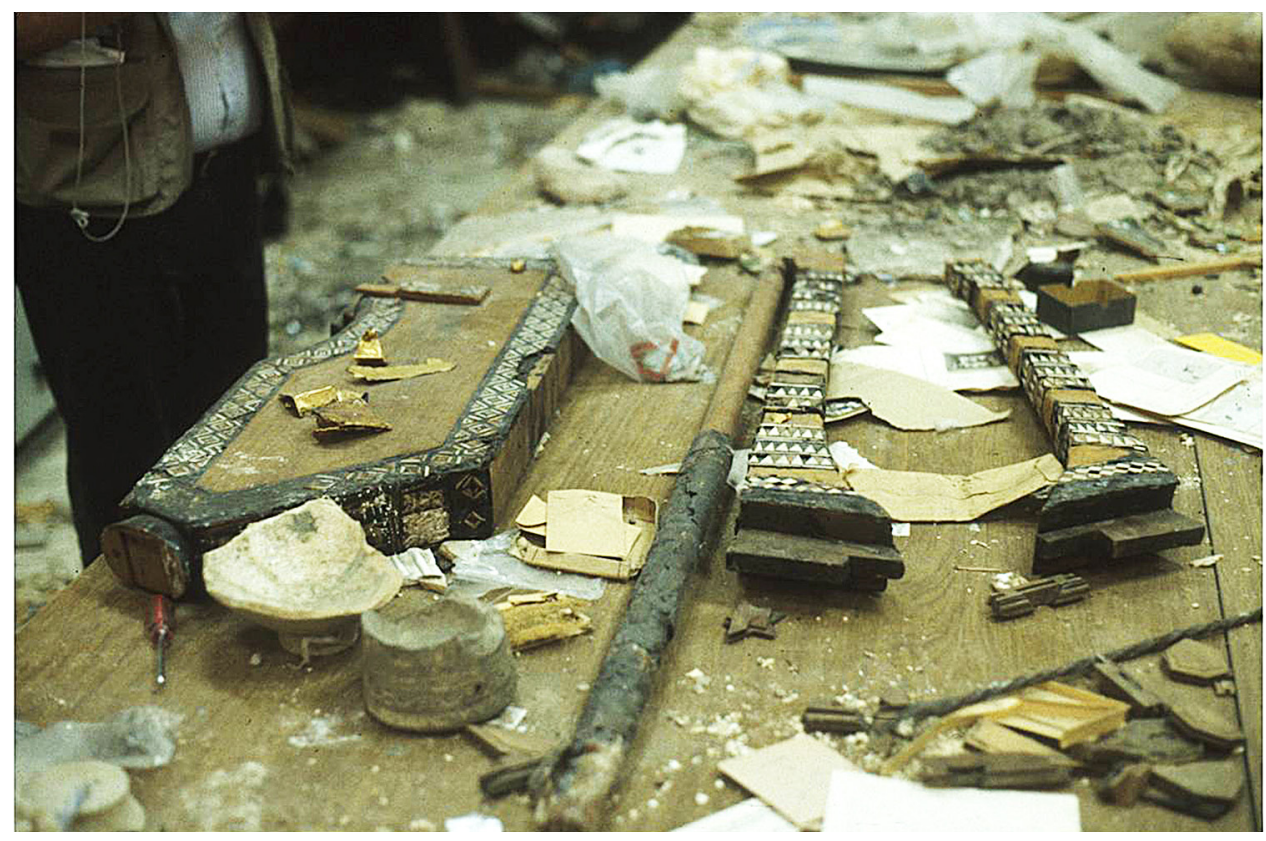

Fig. 5. Golden Lyre of Ur (the world's oldest known stringed musical instrument, ca. 2,600 B.C.E.), destroyed in a storeroom of the Iraq Museum in 2003. 
photographs or drawings of stolen artifacts. But asking the excavators for photographs, receiving them, and incorporating them into a list meant the passage of weeks, during which time the trail of the thieves had grown cold. The importance of a photographic record was recognized by the staff initiating the computerized database in the years before the 2003 war, but afterward, the museum's diminished staff and the fact that many of the objects were in storage for safekeeping meant that scanning for the database was limited.

\section{THE MUSEUM'S ELECTRONIC DATABASE}

The restitution of the Iraq Museum and the SBAH offices in the aftermath of the 2003 looting included the installation of a computer network, which enabled the staff to operate at a higher level of efficiency. The SBAH arranged with UNESCO to create a comprehensive digital data program for the items in the museum, and, with funding by grants from the international community, UNESCO contracted a Canadian company specializing in database management. Senior administrators of the SBAH and the museum's staff discussed the program several times with the company in order to adapt the program to the Iraq Museum's needs. Between 2004 and 2006, 70 operating staff and information technology specialists from the museum were sent to Jordan for training in database management. The equipment arrived at the Iraq Museum in Baghdad, but the work could not be started because of the deterioration of the security situation, which not only forced the sealing of the museum but also caused a significant decrease in the number of museum staff able to come to work.

\section{CONCLUSIONS AND SUGGESTIONS}

There are general lessons to be learned from the experiences of the Iraq Museum in wartime - not just the conflicts in 1991 and 2003 but also going back to the Iran-Iraq War of 1980-1988. It is essential that all museum administrators everywhere be prepared for worst-case scenarios. Any museum could be the victim of looting in a time of social unrest, especially given the current elevated prices for antiquities and works of art. Administrators should have contingency plans for removing artifacts to safekeeping, perhaps outside their countries, if practical, but at least to betterconstructed storerooms than are currently the standard in the Near East. They should also be aware that, in any movement of artifacts from display, labels will be lost or confused, and they should try to develop a method of keeping the information with the object. Some museums in the United States and Europe are beginning to use a barcode system on artifacts, but it is not clear as yet how well that technology will work.

No Iraqi museum I know of has an entirely up-to-date, complete, and easily accessed record of its holdings. This is probably true of most museums that act as repositories of artifacts from excavations, such as national and provincial museums. It would be ideal to have all excavation records, which document part of some museums' holdings, scanned and stored off-site as a backup, whether on the Internet or on special servers in remote locations, or even on several external hard drives. Most museums are understaffed, especially in their records departments, and either digitization of their holdings is just being started or, in the case of those museums that adopted computers early on, their programs are now antiquated and need updating. Paper records, like the excellent ledgers of the Iraq Museum, serve very well if they are kept up-to-date, but computer backups using several modern technologies, such as CDs and DVDs, USB flash drives, and external hard drives, are much easier to transport and can be copied for transfer to multiple safe locations. At a minimum, paper records should be photocopied or scanned, and these duplicates should be deposited outside the country. There should be one or more internationally recognized depositories for duplicates of museum catalogues, photographs, general records, and database storage.

Museums need to photograph and otherwise document every item in their collections; otherwise, no law-enforcement agency will be able to recover them. ${ }^{4}$ UNESCO should inaugurate a program to help museums in particularly vulnerable areas, such as the Middle East, and especially in areas currently under threat, such as Syria and Iran, to document their collections digitally. This help should be expressed in funding for hiring and training local staff, in the supply of adequate and appropriate equipment, and in furnishing expertise. Such

${ }^{4}$ See, e.g., www.fbi.gov/hq/cid/arttheft/asia/iraq/iraqart.htm. 
help should be made available to any museum in need, either through an international effort or through national programs. In the United States, a governmental agency, the Institute of Museum and Library Services, gives grants for museum improvement. Usually, however, these grants are sufficient to begin programs but not to sustain them. In areas of special vulnerability, such as the Middle East, database management needs to be considered an emergency situation, so that resources may be applied to create museum inventories rapidly.

Beyond museums, standing monuments and archaeological sites are part of every country's landscape, and UNESCO should play a role in documenting them. Only strongly committed governments can guard sites effectively, and Iraq, until 1991, had one of the finest records for doing so. Even in the best situations, however, looting can still occur, as is clear from the many cultural heritage thefts in Italy, a country that acts aggressively to prevent and to investigate them. With standing monuments, there is a need for a comprehensive, well-documented database, complete with scale drawings, photographs, and other records. Affixing blue shield markings on the roofs of museums and cultural heritage buildings, so that these buildings will be avoided in air strikes, is essential, and all armies should be trained to recognize and respect such markings. For sites, especially the hundreds of thousands of archaeological mounds in the Near East, which can easily be mistaken for natural hills, the documentation of their precise location is essential, and now with geographic information system (GIS) techniques, it is possible to achieve that precision. In the past three years, Iraq's State Board of Antiquities has had the cooperation of international bodies to train its staff in GIS techniques, including satellite imaging. The SBAH, working with the World Monuments Fund and the Getty Conservation Institute, is establishing a database for the 10,000 or so sites in Iraq that are officially recognized as archaeological sites. But this program has not and cannot safeguard these and the thousands of other sites, which are still being looted on an unprecedented scale in Iraq. ${ }^{5}$ It does, however, help monitor the pace of destruction by means of new images. Imaging will also allow documentation of the spread of looting over time. Such records will be essential in the future when the State Board of Antiquities begins an assessment of the damage done to Iraq's cultural heritage.

In the months before the 2003 Iraq War, a few academics in the United States and Europe furnished lists of sites to the U.S. and the British militaries, and these sites, along with more than 100 standing monuments, were put on the no-strike list. Insofar as we can tell, none of these sites was hit deliberately. The military had also compiled a list of more than 80 buildings to secure in Baghdad, of which the Iraq Museum was number two, but this did not prevent their looting by Iraqis after the fall of Baghdad. Were a country's officials to make such locations known to potential invaders, it would become a political issue; but in the future, it may be essential for countries both to list sites in an international registry and to mark their heritage sites, which might prevent inadvertent bombing and facilitate securing them from looting.

The Iraq Museum was reopened in February 2009, albeit with some objections from Iraqi, American, and European scholars because they all believed that it was not the right time to open the museum on account of the security situation in Baghdad. Nonetheless, reopening has been a positive step forward made by the staffs of the SBAH and the museum. Although the museum is still closed to the general public, eight galleries out of 22 have "opened," though most of the original collection remains in hidden locations; the only objects on display are large items fixed to the floor and the walls and some of the materials that were repatriated after looting. The museum is able to send a number of its staff members for training courses abroad, especially to museums and antiquities institutions in the United States. The current visitors are only VIPs and journalists, but the museum's staff still does its daily work, though not in a healthy political environment, and this is better than nothing.

DEPARTMENT OF ASIAN AND AMERICAN STUDIES

11126 HUMANITIES BUILDING

STONY BROOK UNIVERSITY

STONY BROOK, NEW YORK 11794-5343

DYOUKHANNA@NOTES.CC.SUNYSB.EDU

\footnotetext{
${ }^{5}$ Myers 2010, 25 June.
} 


\section{Works Cited}

Damerji, M.S.B. [1999]. Gräber assyrischer Königinnen aus Nimrud / Qubūr al-malikāt al-ashūriy. Mainz: Verlag des Römisch-Germanischen Zentralmuseums.

Emberling, G., and K. Hanson, eds. 2008. Catastrophe! The Looting and Destruction of Iraq's Past. OIP 28. Chicago: The University of Chicago Press.
Myers, S. 2010, 25 June. "Iraq's Ancient Ruins Face New Looting." The New York Times. http://nytimes. com/2010/06/26/world/middleeast/26looting. html?scr=me (6 August 2010).

Woolley, L., and P.R.S. Moorey. 1982. Ur' 'of the Chaldees': A Revised and Updated Edition of Sir Leonard Woolley's Excavations at Ur. Ithaca, N.Y.: Cornell University Press. 